\title{
Financial crisis and primary health care in Greece. Is it time for family medicine?
}

\author{
Kryzys finansowy i podstawowa opieka medyczna w Grecji. \\ Czy to czas dla medycyny rodzinnej?
}

CHRISTOS LIONISA, D-F

Clinic of Social and Family Medicine, School of Medicine, University of Crete, Greece

A - Study Design, B - Data Collection, C - Statistical Analysis, D - Data Interpretation, E - Manuscript Preparation, $\mathbf{F}$ - Literature Search, $\mathbf{G}$ - Funds Collection

Summary The austerity period in Greece over the past few years has impacted the Greek health care system and more specifically primary care, with the ongoing budget cuts directly affecting the health care sector. This period has impacted access to healthcare services and a great proportion of the population does not receive continuous and personalized care. Primary care is known to be a fragmented system with a lack of integration; the Greek National Health Health System has attempted to improve with clear outcomes; yet there is still room for criticism. A focus of improvements will be considered in the current review. The Greek health care system is unstable and General Practice/Family Medicine still requires further recognition to enhance Primary Care to the general population, although many efforts have been undertaken. The current situation will be explained in this review, examining the tailoring that is required to enhance General Practice/Family Medicine in Greece and if it is necessary. In addition, approaches will be discussed on how to increase the populations' health status and above all to reduce health inequalities; as they are evident in the current health care setting. It is a subject that is receiving prompt attention during this difficult period in Greece.

Key words: performance, development, Greece, general practice, quality improvement.

Streszczenie Okres oszczędzania w Grecji w ciągu kilku ostatnich lat wpłynął na grecki system opieki medycznej, zwłaszcza na podstawową opiekę medyczną, z powodu powtarzanych cięć budżetowych mających bezpośredni wpływ na sektor opieki zdrowotnej. Okres ten wpłynął na dostęp do świadczeń opieki zdrowotnej, a spora część ludności nie jest objęta stałą i indywidualną opieką. Podstawowa opieka medyczna jest systemem rozdrobnionym i brakuje mu integracji. Grecki NFZ próbował go poprawić, osiągając niewątpliwe rezultaty; jednak jest jeszcze miejsce na krytykę. Działania mające na celu usprawnienie systemu będą rozpatrywane w ramach bieżącej pracy. Grecki system ochrony zdrowia jest niestabilny i podstawowa opieka medyczna/medycyna rodzinna wciąż wymagają uznania, że należy zwiększyć dostęp populacji ogólnej do podstawowej opieki zdrowotnej, choć podejmowano już działania w tym celu. Obecna sytuacja jest opisana w bieżącej pracy, w tym działania, które są wymagane w celu wzmocnienia podstawowej opieki medycznej/medycyny rodzinnej w Grecji, i ocena, czy jest to konieczne. Ponadto zostaną omówione strategie na rzecz poprawy stanu zdrowia ludności, a przede wszystkim w celu zmniejszenia nierówności dotyczących zdrowia; są one widoczne w bieżącym działaniu opieki zdrowotnej. To jest temat, który wymaga natychmiastowej uwagi w tym trudnym czasie w Grecji.

Słowa kluczowe: wydajność, rozwój, Grecja, podstawowa opieka medyczna, poprawa jakości.

Fam Med Prim Care Rev 2015; 17(3): 229-231

During the last 4 years, Greece has experienced an austerity period that has severely affected spending on healthcare services and the populations' health has been referred to in the literature as 'the Greek tragedy' [1]. There has been a great impact on access to healthcare services and the use of medications [2-5], while a great proportion of the Greek population is not receiving continuous and personalized care. The efforts undertaken the past years seem to be ineffective in restoring the Greek health care system primarily focusing on short team effects by reducing expenditures [6]. Current health policy discussions focus on the re-organization of primary care services and a restricted budget for medicines and emergency healthcare provision, in a time where the reinvention of primary care in Greece is clearly needed [7].

The Greek health care system is characterized by the coexistence of the National Health System (NHS), a mandatory social insurance and a voluntary private health insurance system. The several attempts to modernize and improve the Greek NHS with a specific reference to primary care has lacked clear outcomes during the past years. The performance of primary care services in Greece has been criticized for the disproportionate or inordinate amount of time allocated to prescribing, repeating prescriptions or ordering diagnostic tests mainly because they lack in integration [8]. This situation exacerbated during the austerity period after the introduction of the electronic prescribing system.

Primary care physicians recognize and report the impact of austerity on health care services; Greek rural GPs are expressing their unmet professional expectations, concern and great uncertainty about the future quality of primary care services available, and their role as providers of care [9].

Based on all of the above, currently General Practice/ Family Medicine (GP/FM) is still trying to seek the interna- 
tional merit it deserves while it requires further development during the current health care policy reform. However, the interest of the Greek states about GP/FM as an independent clinical discipline dates back to 1986, with approximately 2,000 Greek physicians specialized in GP/FM until today.

Considering the uncoordinated and fragmented primary care system [8], efforts to improve this area by developing the first practice guidelines for primary care was conducted by the University of Crete with the joint cooperation of the Greek Society of General Practice (ELEGEIA), national societies of clinical medical specialists and a nurses association (ENE) (http://www.greekphcguidelines.gr/en/). This national project conducted an extensive literature review which led to an international expert consensus panel to develop thirteen valuable guidelines to improve quality in clinical practice. This project utilised a modified algorithm introduced by Kaiser Permanente [9] and the ADAPTE methodological framework (http://www.adapte.org) [10] upon approval. A list of evidence-based guidelines issues by known Colleges or Institutes of Family Medicine and the literature has been reviewed and appraised with the use of translated into Greek assessment tools, also after approval. Two stages approach with a Delphi methodology was performed to formulate consensus based statements to the Greek GPs and primary care nurses jointly presented with their level of evidence and recommendation.

Teamwork and multidisciplinary work are still lacking in both the public and private health care sector. Primary care nursing has a restricted role and nurses that serve rural populations clearly seek for training and recognition of their role [11-13]. All the above contribute to the reasons why Greece ranked low when quality and performance in PHC was mapped by European comparative studies [14]. Continuity requires many efforts for improvement as a recent European study showed [15]. Quality improvement and continuous professional development is in the current debate in Greece and a discussion on the role of the scientific societies and institutes is in process, with ELEGEIA attempting for a national strategy to promote the clinical and academic discipline. The academic discipline is also still striving to receive recognition [16], while the poor research capacity in primary care in Greece has also affected the funding for research and the active involvement of General Practice in clinical research, especially in clinical effectiveness. Even with a theoretical framework that was designed a few years back, practice-based research and networking remains restricted [17]. Multiple research projects have already been implemented in examining effectiveness of various interventions carried-out in the primary care setting either through national or European funded projects $[18,19]$. Networking for research is still lacking and funding for collaborative research from EU is limited in Greece with some exceptions, where the University of Crete and the Cretan practice-based research network is involved (http://fp7restore.eu/, http://euwise.com/, http://www.otcsociomed.uoc.gr/joomla/).

During the financial constraints that Greece is encountering, there are consequences on the populations' health with many areas not currently addressed in the agenda of GP/FM and many themes including multi-morbidity, frailty and self-management are currently on debate in the international setting. The cutting of health care services during an economic crisis for the minority populations is common and the negative effects of such actions are only starting to emerge in Greece [20].

Taking all the above into consideration, it is evident that GP/FM in Greece remains to have a weak voice without strategic proposals during health care reforms. Even with ELEGEIA, that represents GPs globally and at WONCA, this discipline is still seeking recognition and efforts in promotion and educational activities [21].

GP/FM in Greece should also consider the impact of the financial crisis on the populations' health and explore ways to increase the access to a more patient-centered and compassionate approach to care and reduce the health inequalities. Patient-centered care is on the focus in both Europe and US where the patient-centered medical home model has received much interest in the past few years [22]. In the same line, compassionate care has gained prompt attention in the literature [23-25] and it seems that it is a fertile ground where GP/FM could invest energy and efforts in a time where proposals about the future of this discipline and PHC in Greece have been already reported in the literature [6, 26, 27]. There remains to see how this discipline in Greece will raise its voice and document its intervention to alleviate the burden that has been left to the Greek population. It requires many efforts of coordination within the national setting and networking in the international setting.

Source of funding: This work was funded by the author's resources.

Conflict of interest: The author declares no conflict of interests.

\section{References}

1. Kentikelenis A, Karanikolos M, Papanicolas I, et al. Health effects of financial crisis: omens of a Greek tragedy. Lancet 2011; 22: 378

2. Sbarouni V, Tsimtsiou Z, Symvoulakis E, et al. Perceptions of primary care professionals on quality of services in rural Greece: a qualitative study. Rural and Remote Health 2012; 12: 2156. (Online) Available: www.rrh.org.au (Accessed 6 March 2013).

3. Karatzanis AD, Symvoulakis EK, Nikolaou V, et al. Potential impact of the financial crisis on outpatient hospital visits due to otorhinolaryngologic disorders in Crete, Greece. Int J Med Sci 2012; 9(2): 126-128.

4. Kalafati M. How Greek healthcare services are affected by the Euro crisis. Emerg Nurse 2012; 20(3): 26-27.

5. Karamanoli E. Greece's financial crisis dries up drug supply. Lancet 2012; 379(9813): 302.

6. Simou E, Koutsogeorgou E. Effects of economic crisis on health and healthcare in Greece in the literature from 2009 to 2013 : A systematic review. Health Policy 2014; 115: 111-119.

7. Simou E, Karamagioli E, Roumeliotou A. Reinventing primary health care in the Greece of austerity; the role of health-care workers. Prim Health Care Res Develop 2015; 16: 5-13.

8. Lionis C, Symvoulakis EK, Markaki A, et al. Integrated primary health care in Greece, a missing issue in the current health policy agenda: a systematic review. Int J Integr Care 2009; 9: e88.

9. Modified algorithm introduced by Kaiser Permanente (2012).

10. Robays J, Vlayen J. ADAPTE Methodological Framework. (Online) Available: http://processbook.kce.fgov.be/node/103.

11. Tsiligianni I, Anastasiou F, Antonopoulou M, et al. Greek rural GPs' opinions on how financial crisis influences health, quality of care and health equity. Rural and Remote Health 2013; 13: 2528. (Online) Available: http://www.rrh.org.au

12. Markaki A, Alegakis A, Antonakis N, et al. Exploring training needs of nursing staff in rural Cretan primary care settings. Appl Nurs Res 2009; 22(2): 138-143

13. Markaki A, Lionis C. Capacity building within the primary healthcare nursing: a current European challenge. Qual Prim Care 2008; 16(6): 385-386. 
14. Kringos D, Boerma W, Bourgueil Y, et al. The strength of primary care in Europe: an international comparative study. Br J Gen Pract 2013; 63(616): e742-e750.

15. Schafer W, Boerma W, Murante AM, et al. Assessing the potential for improvement of primary care in 34 countries: a cross-sectional survey. Bull World Health Org 2015; 93: 161-168.

16. Lionis C, Carelli F, Soler JK. Developing academic careers in family medicine within the Mediterranean setting. Fam Pract 2004; 21(5): 477-478.

17. Lionis C, Symvoulakis EK, Vardavas CI. Implementing family practice research in countries with limited resources: a stepwise model experienced in Crete, Greece. Fam Pract 2010; 27(1): 48-54.

18. Duijker G, Bertsias A, Symvoulakis EK, et al. Reporting effectiveness of an extract of three traditional Cretan herbs on upper respiratory tract infection: Results from a double-blind randomized controlled trial. J Ethnopharmacol 2015; 163: 157-166.

19. Kostopoulou O, Lionis C, Angelaki A, et al. Early diagnostic suggestions improve accuracy of family physicians: a randomized controlled trial in Greece. Fam Pract 2015; [Epub ahead of print].

20. O'Donnell, Burns N, Dowrick C, et al. Health-care access for migrants in Europe. Lancet 2013; 382: 393-394.

21. Lionis C. Is there any room for General Practice in Greece? A proposal to scientific and academic stakeholders. Hippokratia 2014; 18: 4

22. Agency for Healthcare Research and Quality. Patient-centered Medical Home: Resource Center, Available from URL: http:// pcmh.ahrq.gov/.

23. Lionis $C$, Shea S. Restoring humanity in health care through the art of compassion: an issue for the teaching and research agenda in rural health care. Rural and Remote Health 2010; 10: 1679. (Online) Available: http://www.rrh.org.au.

24. Lionis C, Shea S. Enhancing compassionate care as an integral part of primary care and general practice. GJMEDPH $2012 ; 1: 5$.

25. Shea S, Lionis C. Introducing the Journal of Compassionate Health Care. J Compassion Health Care 2014; 1: 7.

26. Kousoulis AA, Angelopoulou KE, Lionis C. Exploring health care reform in a changing Europe: lessons from Greece. Eur J Gen Pract 2013; 19(3): 194-199.

27. Groenewegen PP, Jurgutis A. A future for primary care for the Greek population. Qual Prim Care 2013; 21(6): 369-378.

Address for correspondence:

Prof. Christos Lionis

University of Crete Medical School

70013 Voutes Residential Area

Greece

Phone: +302810394621

E-mail: lionis@galinos.med.uoc.gr

Received: 30.03.2015

Revised: 25.04.2015

Accepted: 29.04.2015 